\title{
Seroprevalence of Low Pathogenic Avian Influenza (H9) in Sonali Chickens of Joypurhat
}

\author{
Md. Ziaur Rahman', S.M. Harun-ur- Rashid², Md. Golam Azam³*, Md. Nuruzzaman4, \\ Md. Gausur Rahman ${ }^{5}$ \\ ${ }^{1}$ Upazila Livestock Officer, Upazila Livestock Office, Badalgachi, Naogaon, Bangladesh \\ ${ }^{2, * 3}$ Department of Pathology and Parasitology, Hajee Mohammad Danesh Science and Technology \\ University, Dinajpur, Bangladesh \\ ${ }^{4}$ Lecturer, Dept. of Pathology and Parasitology, Sirajganj Government Veterinary College, \\ Sirajganj, Bangladesh \\ ${ }^{5}$ Livestock Extension Officer, Upazila Livestock Office, Rajbari sadar, Rajbari, Bangladesh
}

*(dr.azamrs@gmail.com)

\begin{abstract}
This journal is licensed under a Creative Commons Attribution-Noncommercial 4.0 International License (CC-BY-NC). Articles can be read and shared for noncommercial purposes under the following conditions:

- BY: Attribution must be given to the original source (Attribution)

- NC: Works may not be used for commercial purposes (Noncommercial)

This license lets others remix, tweak, and build upon your work non-commercially, and although their new works must also acknowledge you and be non-commercial, they don't have to license their derivative works on the same terms.

License Deed Link: http://creativecommons.org/licenses/by-nc/4.0/

Legal Code Link: http://creativecommons.org/licenses/by-nc/4.0/legalcode

$A B C$ Research Alert uses the CC BY-NC to protect the author's work from misuse.
\end{abstract}

\begin{abstract}
The present study was designated to know the sero-prevalence status of $\mathrm{H9}$ antibodies in Sonali chickens at Joypurhat district in Bangladesh by initial screening of AIV type A by ELISA followed by H9 LPAI detection by HI test. 180 sera samples from 18 flocks were collected and screened for Avian Influenza Virus type A antibodies by ELISA. All ELISA positive samples were tested by HI test, specific for $\mathrm{H} 9$ antibodies. On ELISA, sero-prevalence for AIV type A were $14.4 \%$ and $3.3 \%$ in older aged group ( $\geq 11$ weeks) and growing aged group ( $\leq 10$ weeks) respectively, with an overall seroprevalence of $8.89 \%$ in Sonali chickens at Joypurhat district. Among these AIV sero-positive samples, $\mathbf{9 2 . 3 1 \%}$ of older aged group and $66.67 \%$ of growing aged group chickens found seropositive to $\mathrm{H} 9$ antibodies by $\mathrm{HI}$ test with an overall $87.5 \%$. Out of 180 sera samples, only 14 samples found positive to $\mathrm{H} 9$ antibodies, indicating $7.78 \%$ sero-prevalence in Sonali chickens of Joypurhat district. This study revealed higher sero-prevalence of AIV antibodies as well as $\mathbf{H 9}$ antibodies in older aged group which might be due long-time exposure to infections. Seroprevalence of both AIV type A and H9 LPAI are higher in older aged Sonali chickens. The findings of the present study suggest that the overall seroprevalence of AIV type A and H9 LPAI in Sonali chickens are $8.89 \%$ and $\$ .78 \%$ respectively, at Joypurhat district in Bangladesh and also suggest that H9LPAI virus in circulation in Sonali chickens at Joypurhat district in Bangladesh.
\end{abstract}

Keywords

Sero-prevalence, Avian Influenza, Sonali Chicken, ELISA, Sera

\section{INTRODUCTION}

Commercial poultry farming in Bangladesh is growing rapidly; in the nineties, the total investment in the poultry sector was only Tk 15 billion, but now it is more than Tk 150 billion. This industry has a 
great potential for boosting the economic growth of the country as well as ensuring food security (Ali and Hossain, 2012).

Avian influenza is an important poultry disease caused by Type A influenza viruses under the family Orthomyxoviridae, that can cause mild to severe infection in different avian species resulting in severe damage to the poultry industry. Influenza A viruses infecting poultry are divided into two groups based on their pathogenicity: highly pathogenic avian influenza (HPAI) which cause generalized rather than respiratory disease with flock mortality as high as $100 \%$ and low pathogenic avian influenza (LPAI) which usually causes much milder respiratory disease with low mortality if there are no secondary viral and/or bacterial infection or poor environment condition (OIE Manual, 2009).

In 2003 to 2004, HPAI virus caused multiple and widespread poultry outbreaks in many Asian countries, including Cambodia, China, Indonesia, Japan, South Korea, Laos, Malaysia, Thailand and Vietnam. Stamping-out has been the national policy in Bangladesh in combating H5N1 HPAI. Recently vaccination against $\mathrm{H} 5 \mathrm{~N} 1$ has been introduced on trial basis. Non-H5 or non-H7 AI isolates that are not virulent for chickens are identified as LPAI (OIE, 2009). Low pathogenic avian influenza viruses H9N2 became panzootic in the mid-1980s among multiple avian species in Asia, the Middle East, Africa and Europe. The H9N2 viruses infection is generally characterized by mild respiratory infections, however nowadays these viruses produce significant disease problems associated with high mortality in poultry. Although H9N2 viruses are characterized as LPAI viruses, they may cause high morbidity and mortality that may increase the risk of infections of H5N1 HPAI (Park et al., 2001).

Low pathogenic H9N2 viruses are circulating in poultry farms of Bangladesh (Negovetich et al., 2011; Jannat et al., 2013; Shanmuganatham et al., 2013; Parvin et al., 2014). Both HPAIV H5N1 and AIV H9N2 are co-circulating among poultry population in many Eurasian countries mostly reported from Bangladesh, China, India, Pakistan, Vietnam, Israel, Egypt and United Arab Emirates. Although the LPAI is circulating in Bangladesh, there are very limited studies on LPAI even not in Sonali Chickens. There are no activities for controlling LPAI in Bangladesh.

The research work is aimed to study the Prevalence of Avian influenza type-A as well as LPAI in Sonali Chickens at Joypurhat District for the prevalence study of LPAI in Sonali Chickens and detection of antibodies to avian influenza type-A in Sonali Chickens in Joypurhat district.

\section{MATERIALS AND METHODS}

\section{Research Area}

Samples were collected from Sonali chicken raring farms at Joypurhat and most of the laboratory research work was conducted in the Central Disease investigation Laboratory (CDIL), Department of Livestock services, Dhaka.

\section{Research Period}

The duration of experiment was 6 months from June, 2015 to December, 2015.

\section{Equipment}

Balance (AND, USA); Microcentrifuge (Eppendorf, Germany) Bench centrifuge; ClassII Biosafety cabinet (ESCO, Singapore); Micropipettes (Eppendorf, Germany); pH meter; Vortexer; Benchtop autoclave; Refrigerators, Freezers, ELISA Reader (Multiskan-EX Lab system, Thermo-scintific) etc.

\section{Plastic Ware and Other consumables}

Pipette tips (Eppendorf, Germany); Falcon tubes: $15 \mathrm{ml}$ (Becton Dickinson Labware, USA and Eppendorf, Germany); Sterile filter tips (Eppendorf, Germany); Syringe and Needle (Opsonin, Bangladesh), etc.

\section{Sera samples}

A total of 180 blood Samples of Sonali Chickens of different age groups were collected from farms of 
Joypurhat District in this study and subjected to ELISA and HI test.

\section{Test Kits and Reagents}

\begin{tabular}{|c|c|c|}
\hline Test kit & Use & Source \\
\hline $\begin{array}{l}\text { Avian Influenza Antibody } \\
\text { test ELISA kit }\end{array}$ & $\begin{array}{l}\text { Type-A AIV antibody detection } \\
\text { based on Matrix protein }\end{array}$ & IDEXX( U S A) \\
\hline H9 antigen & $\begin{array}{l}\text { HI test to detect H9N2 antibody } \\
\text { in serum }\end{array}$ & $\begin{array}{l}\text { Newcastle and Avian influenza } \\
\text { Reference Laboratory, Italy }\end{array}$ \\
\hline
\end{tabular}

Table-1: Test kits and Antigen used in the present study

\section{Solutions, Buffers and Chemicals}

1X PBS, Alsever's solution, 1\% Chicken RBC were used in the present study.

\section{METHODS}

\section{Blood Collection and Sera Separation}

$>1 \mathrm{ml}$ of each of 180 blood samples from Sonali chickens were collected in $3 \mathrm{ml}$ disposable syringe and lebelled with separate numbering. Samples were collected from those Sonali chicken rearing farms which have previous history of respiratory illness at Joypurhat.

$>$ The syringe containing blood samples were then kept in horizontal position at room temperature overnight to separate serum from the collected blood.

$>$ Sera samples were then transferred to separate eppendorf tube $(1.5 \mathrm{ml})$ and subjected to low speed centrifuge at $1000 \mathrm{rpm}$ for 5 minutes and supernatant were collected as serum samples in separate labeled eppendorf tube.

$>$ Separeted serum samples were then stored at $-20^{\circ} \mathrm{C}$ until use.

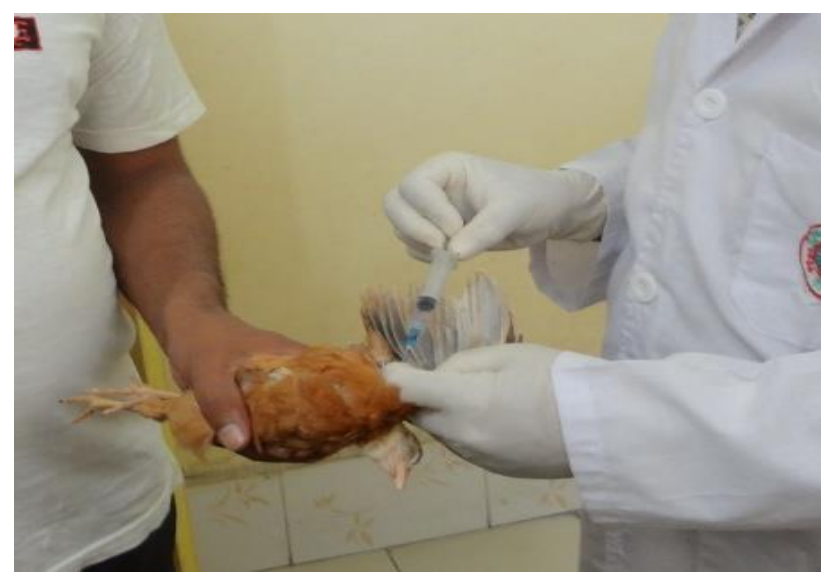

Figure 1: Collection of blood from Sonali chicken

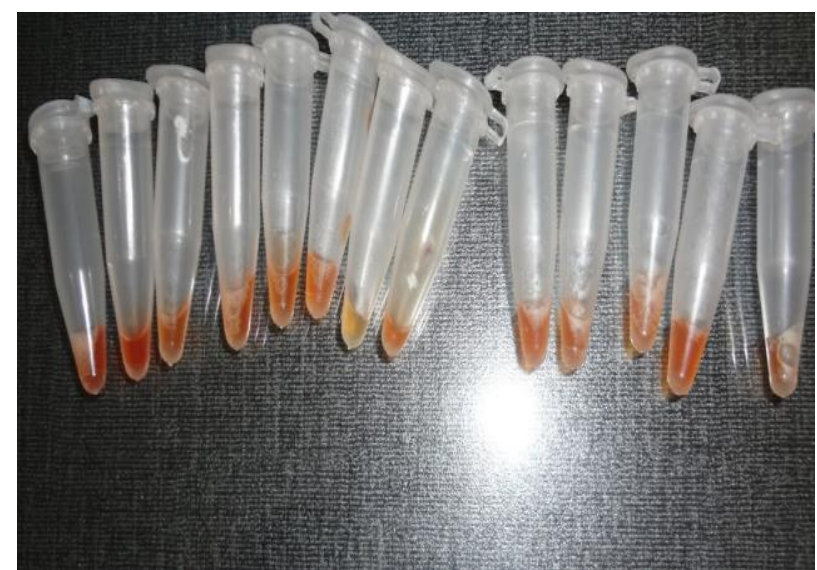

Figure 2: Sera sample collected from chicken blood

\section{Elisa Test for AIV Type - A Antibody}

The Elisa Kit was obtained from Biocheck Company. ELISA test was done following manufacturer's instruction.

\section{Calculation of Result}

The relative levels of antibodies in the unknown samples were determined by calculating samplepositive (S/P) ratio. The equation of calculation provided in ELISA kit was used for the calculation of antibody titer. 


\section{Hemagglutination (Ha) Test for Preparing Of 4hau Antigen}

$>25 \mu \mathrm{L}$ of PBS was added to each of the well in 96 well V-bottomed plastic microtiter plate.

$>$ Then $25 \mu$ l of antigen (H9N2) was added at first row and serial two-fold dilution was done up to $11^{\text {th }}$ well and 12 th well was kept as control.

$>$ Again, $25 \mu \mathrm{L}$ of PBS was added to each of the well in 96 well V-bottomed plastic microtiter plate.

$>25 \mu \mathrm{L}$ freshly prepared $1 \%(\mathrm{~V} / \mathrm{V})$ Chicken $\mathrm{RBC}$ was then added into each well and mixed by tilting and kept at room temperature for 30 minutes.

$>$ The higest dilution of antigens that completely agglutinate the chicken RBC was recorded as 1 HAU.

4HAU was prepared with PBS for the use on Hemagglutination Inhibition test.

\section{Hemagglutination Inhibition (Hi) Test for H9 Subtype Detection}

$\mathrm{HI}$ test was done as per instruction outlined in OIE manual. Briefly,

$>25 \mu \mathrm{L}$ of PBS was added to each of the well in 96 well V-bottomed plastic microtiter plates.

$>$ Then $25 \mu 1$ of ELISA positive sera was added into the first well of each row separately and recorded properly.

$>$ Two-fold serial dilutions of sera were made across the row up to $11^{\text {th }}$ well and $12^{\text {th }}$ well kept as control.

$>\quad 25 \mu \mathrm{L}$ of $4 \mathrm{HAU}$ avian influenza virus subtype H9N2 was added into each well up to $11^{\text {th }}$ well in each row and incubated at room temperature for 30 minutes.

$>25 \mu \mathrm{L}$ freshly prepared $1 \%(\mathrm{~V} / \mathrm{V})$ Chicken $\mathrm{RBC}$ was then added into each well and mixed by tilting and kept at room temperature for 40 minutes.

$>$ The highest dilution of the test sera that completely inhibited the RBC agglutination was recorded as antibody titre against $\mathrm{H} 9 \mathrm{~N} 2$.

$>$ Titer of $\mathrm{H} 9$ antibody in the test sera $\geq \log _{2}{ }^{4}$ was considered as positive (Ghaniei et al., 2013).

$>$ The titer was analyzed statistically by measuring arithmetic mean titer (AMT).

\section{RESULTS}

The present study revealed that 3 out of 90 samples of $\leq 10$ weeks aged group were positive and 13 out of 90 samples of aged group $\geq 11$ weeks were positive. The sero-prevalance of avian influenza type A was $3.3 \%$ and $14.4 \%$ in $\leq 10$ weeks aged group and $\geq 11$ weeks aged group respectively. The overall sero- prevalence of AIV antibodies in sonali chicken at Joypurhat district was $8.89 \%$.

\begin{tabular}{|c|c|c|c|c|c|}
\hline Age group & $\begin{array}{c}\text { No of samples } \\
\text { tested }\end{array}$ & $\begin{array}{c}\text { No of ELISA } \\
\text { positive samples }\end{array}$ & $\begin{array}{c}\text { No of ELISA negative } \\
\text { samples }\end{array}$ & $\begin{array}{c}\text { Sero-prevalence } \\
(\%)\end{array}$ & $\begin{array}{c}\text { Over all sero- prevalence } \\
(\%)\end{array}$ \\
\hline$\leq 10$ weeks & 90 & 3 & 87 & 3.3 & \multirow{2}{*}{8.89} \\
\hline$\geq 11$ weeks & 90 & 13 & 77 & 14.4 & \\
\hline Total & 180 & 16 & 164 & & \\
\hline
\end{tabular}

Table-2: Sero-prevalence of avian influenza type A in sonali chickens of Joypurhat district

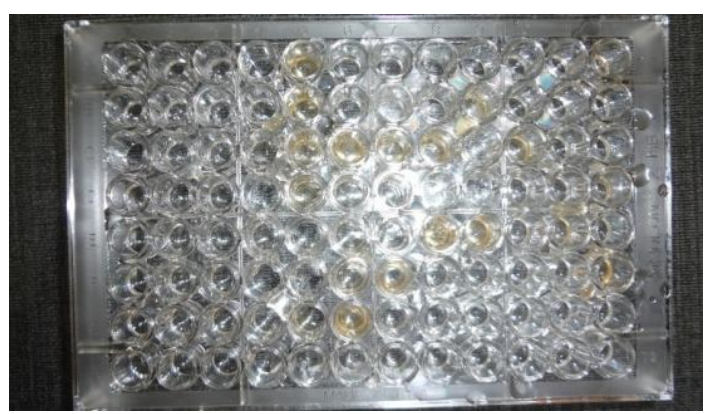

Figure 3: ELISA Plate 


\section{Hemaglutination Inhibition Test}

All 16 AIV type A positive sera on ELISA test were subjected to HI test. 14 samples out of 16 samples were positive on HI test with HI titer $>\log _{2}{ }^{4}$. Results are presented in Table-3.

\begin{tabular}{|c|c|c|c|c|}
\hline Age group & $\begin{array}{c}\text { ELISA positive } \\
\text { Sample }\end{array}$ & $\begin{array}{c}\text { HI titer } \\
\left(\log _{2}\right)\end{array}$ & AMT & $\% \mathrm{CV}$ \\
\hline \multirow[b]{3}{*}{$\leq 10$ weeks } & 1 & 3 & \multirow{3}{*}{4.33} & \multirow[t]{3}{*}{35.2} \\
\hline & 2 & 4 & & \\
\hline & 3 & 6 & & \\
\hline \multirow[t]{13}{*}{$\geq 11$ weeks } & 1 & 6 & \multirow[t]{13}{*}{5.62} & \multirow[t]{13}{*}{26.7} \\
\hline & 2 & 4 & & \\
\hline & 3 & 8 & & \\
\hline & 4 & 5 & & \\
\hline & 5 & 6 & & \\
\hline & 6 & 7 & & \\
\hline & 7 & 4 & & \\
\hline & 8 & 7 & & \\
\hline & 9 & 6 & & \\
\hline & 10 & 7 & & \\
\hline & 11 & 6 & & \\
\hline & 12 & 4 & & \\
\hline & 13 & 3 & & \\
\hline
\end{tabular}

Table-3: Results of ELISA test and HI test

\section{DISCUSSION}

AIV causes frequent epidemics and occasional pandemics in various animals and thus present a significant public health problem associated with considerable economic consequences. AIVs of various subtypes are circulating in poultry (Abbas et al., 2010; Jeong et al., 2010; Kim et al., 2010). In particular, H5N1 and H9N2 AIVs are predominant among poultry flocks causing severe disease outbreaks with high morbidity and mortality (Nagarajan et al., 2009; Xu et al., 2007; Cameron et al., 2000) in many countries including Bangladesh.

180 sera samples from 18 flocks were collected and screened for AIV type A antibodies by ELISA. ELISA positive samples were subjected to HI test, specific for $\mathrm{H} 9$ antibodies. On ELISA, seroprevalence for AIV type A were $3.3 \%$ and $14.4 \%$ in growing aged group ( $\leq 10$ weeks) and older aged group ( $\geq 11$ weeks) respectively, with an overall sero-prevalence of $8.89 \%$ in sonali chickens at Joypurhat district. Among, these AIV sero-positive samples, $66.67 \%$ of growing aged group and $92.31 \%$ of older aged group chickens found sero-positive to $\mathrm{H} 9$ antibodies by $\mathrm{HI}$ test with an overall of $87.5 \%$. Out of 180 sera samples, only 14 samples found positive to $\mathrm{H} 9$ antibodies, indicating $7.78 \%$ sero-prevalence in sonali chickens of joypurhat district. This study revealed that sero-prevalence of AIV antibodies as well as $\mathrm{H} 9$ antibodies is higher in older aged group which might be due long-time exposure to infections as the virus is in circulation since 2006 (Parvin et al. 2013). Similar studies were done by Nooruddin et al. (2006) on native chicken of Bangladesh and found over all 8.92\% sero-prevalence of AIV antibodies. In another studies, conducted by Alam et al. (2003) found 14\% sero-positive native birds in Bogra district. Findings of both studies are nearly close to the present study, although, Alam et al. (2010) recorder higher sero-prevalence in other district of Bangladesh (Cox's Bazar 38.60\% and Barishal 32.30\%).Cheng et al. (2002) found 7\% H9 sero-positive chicken and Li et al. (2004) found $12.8 \% \mathrm{H} 9$ sero-positive chickens in their study areas. Antibody against Avian influenza may be found at any age (OIE, 2013) of birds.

\section{CONCLUSION}

So the present study may be concluded as;

a) Sero-prevalence of both AIV type A and H9 LPAI are higher in older aged Sonali Chickens.

b) H9 LPAI is in circulation in Sonali chickens at Joypurhat District in Bangladesh. 
c) The overall seroprevalence of AIV type A and H9 LPAI in Sonali Chickens are $8.89 \%$ and $7.78 \%$ respectively, at Joypurhat district in Bangladesh.

d) Further studies can be taken to find out the LPAI scenario in Bangladesh.

\section{REFERENCES}

Abbas MA, Spackman E, Swayne DE, Ahmed Z, Sarmento L, Siddique N, Naeem K, Hameed A, Rehmani S. 2010: Sequence and phylogenetic analysis of H7N3 avian influenza viruses isolated from poultry in Pakistan 19952004. Virological Journal 7:137.

Alam J, Giasuddin M, Samad MA, Mjfa Taimur 2010: Recent evidence of Avian Influenza in Bangladesh: A review, Worlds Poultry Science. J 66: 455-464.

Ali MM, Hossain MM 2012: Problems and Prospects of Poultry industry in Bangladesh: An Analysis. American International University of Bangladesh (AIUB) Business and Economics Working paper series.No.2012-1 http://orp.aiub.edu/ Working paper.aspx.

Cameron KR, Gregory V, Banks J, Brown IH, Alexander DJ, Hay AJ, Lin YP 2000: H9N2 subtype influenza A viruses in poultry in Pakistan are closely related to the H9N2 viruses responsible for human infection in Hong Kong. Virology 278:36-41

Jannat N, Chowdhury EH, Parvin R, Begum JA, Giasuddin M, Khan MAHNA, Islam, MR 2013: Investigation of an Outbreak of Low Pathogenic Avian Influenza in Poultry in Bangladesh; International Journal of Livestock Research 321-32.

Jeong OM, Kim YJ, Choi JG, Kang HM, Kim MC, Kwon JH, Lee YJ. 2010: Genetic characterization of H1 avian influenza viruses isolated from migratory birds and domestic ducks in Korea.Virus Genes. 42:55-63.

Kim HR, Lee YJ, Lee KK, Oem JK, Kim SH, Lee MH, Lee OS, Park CK. 2010: Genetic relatedness of H6 subtype avian influenza viruses isolated from wild birds and domestic ducks in Korea and their pathogenicity in animals. Journal of General Virology 91:208-19.

Li CH, Zhou XZ, Li MX. 2004: Discoveries of avian influenza A (H9N2) virus in chickens and men infected by H9N2 virus in Guangzhou area. Zhonghua. Chinese Journal of Experimental and Clinical Virology 18:213-214.

Nagarajan S, Rajukumar K, Tosh C, Ramaswamy V, Purohit K, Saxena G, Behera P, Pattnaik B, Pradhan HK, Dubey SC. 2009: Isolation and pathotyping of H9N2 avian influenza viruses in Indian poultry. Veterinary Microbiology 133:154-63.

Negovetich NJ, Feeroz MM, Jones-Engel L, Walker D, Alam SM, Hasan K, Seiler P, Ferguson A, Friedman K, Barman S, Franks J, Turner J, Krauss S, Webby

Nooruddin GM, Hossain MT, Mohammad M, Rahman MM. 2006: Seroepidemiology of avian influenza virus in native chicken in Bangladesh. International Journal of Poultry Science 5:1029-1033.

OIE 2009: Update on highly pathogenic avian influenza in animals (type H5 and H7). Office International des Epizooties, www.oie.int

OIE 2013: World Animal Health Information Database (WAHID) Interface. Disease Information. Available at http://www.oie.int/wahis_2/public/wahid.php/ Disease information/ Immsummary (Accessed on 25 July 2013)

Park CH, Ozaki H, Takada A. 2001: Primary target cells of virulent strains of type A influenza virus in chicken embryos. Avain Pathology 30:269-72.

Parvin R, Heenemann K, Halami MY, Chowdhury E H, Islam MR, Vahlenkamp TW 2014: Full-genome analysis of avian influenza virus H9N2 from Bangladesh reveals internal gene reassortments with two distinct highly pathogenic avian influenza viruses.Archives of Virology, DOI 10.1007/s00705-014-1976-8

Parvin R, Heenemann K, Halami MY, Chowdhury EH, Islam MR, Vahlenkamp TW. 2014a: Fullgenome analysis of avian influenza virus H9N2 from Bangladesh reveals internal gene reassortments with two distinct highly pathogenic avian influenza viruses. Archives of Virology 159(7):1651-61.

RJ, Webster RG 2011: Live bird markets of Bangladesh: H9N2 viruses and the near absence of highly pathogenic H5N1 influenza.PLoS One 6 e19311.

Shanmuganatham K, Feeroz MM, Jones-Engel L, Smith GJD, Fourment M, Walker D, McClenaghan L, Alam SMR, Hasan MK, Seiler P, Franks J, Danner A, Barman S, McKenzie P, Krauss S, Webby RJ, WebsterRG 2013: Antigenic and molecular characterization of avian influenza A (H9N2) viruses, Bangladesh. Emerging Infectious Diseases 19 (DOI:10.3201/eid1909.130336).

Xu KM, Smith GJ, Bahl J, Duan L, Tai H, Vijaykrishna D. 2007: The genesis and evolution of H9N2 influenza viruses in poultry from southern China, 2000 to 2005. Journal of Virology 81(19): 10389-401 